\title{
Agronomic And Economic Performance Of Different Soy Cultivars
}

\author{
Desempenhos Agronômico E Econômico De Diferentes Cultivares De Soja
}

Rafael da Silva Cabral ${ }^{1}$, Ricardo Francischini, Stella Vannucci Lemos ${ }^{1}$, Indiamara Marasca ${ }^{1}$

${ }^{1}$ UniRV, marasca_7@hotmail.com*

Info

Recebido: $14 / 08 / 2018$

Publicado: $14 / 11 / 2018$

DOI: 10.29247/2358-260X.2018v5i3.p4-14

ISSN: 2358-260X

\section{Palavras-Chave}

Glycine Max, época de semeadura, custo de produção.

\section{Keywords:}

Glycine Max; sowing season; production costs.

weight of a thousand grains and productivity. The seeded soybean cultivars were M 7110 IPRO, M 7739 IPRO, TMG 7262 RR and SYN 1163 RR. For statistical analysis, the F test was performed and, according to significance, the Tukey test was performed at $5 \%$. In the tested varieties, a statistical difference of plant height occurred in the two sowing seasons, except the variety M 7739 IPRO. At the time of insertion of the first pod, all cultivars showed a proximity between the two sowing times. In the weight of a thousand grains, the cultivar M 7739 IPRO did not differ its weight independent of the sowing times, the others, already in the second season, its weight was lower when compared to the first season. The yield did not show significant difference between all four cultivars tested in the two sowing seasons. When all losses are accounted for and converted to the initial cost of seeds used for sowing, it generates a revenue that presents losses that result in lower productivity, failing to produce an additional revenue that can be used within the agricultural enterprise itself.

\section{Resumo}

A soja Glycine Max (L) Merr, pertencente à família Fabaceae é uma espécie leguminosa de alto valor socioeconômico com vários produtos e subprodutos utilizados na fabricação de alimentos e rações. 0 estudo teve como objetivo realizar análises de viabilidade técnica e econômica na cultura da soja, na região central do Brasil, em duas épocas de plantio, utilizando quatro variedades de sementes, duas com a tecnologia Roundup Ready® (RR)e duas com a tecnologia INTACTA RR2 PRO ${ }^{\mathrm{TM}}$. 0 experimento foi conduzido no Centro de Pesquisa Agrícola - CPA, município de Rio Verde, GO. 0 delineamento experimental utilizado foi em blocos casualizados. Foram avaliadas populações inicial e final para levantamento de perdas e produtividade estimadas de cada cultivar, altura de planta, inserção de primeira vagem, peso de massa de mil grãos e produtividade. As cultivares de soja semeadas foram M 7110 IPRO, M 7739 IPRO, TMG 7262 RR e SYN 1163 RR. Para análise estatística foi realizado o teste F e conforme a significância procedeu-se ao teste de Tukey a 5\%.Nas variedades testadas todas ocorreram uma diferença estatística de altura de planta nas duas épocas de semeadura, exceto a variedade M 7739 IPRO. Na altura de inserção de primeira vagem, todas as cultivares apresentaram uma proximidade entre as duas épocas de semeadura. No peso de massa de mil grãos, a cultivar M 7739 IPRO não diferiu seu peso independente das épocas de semeadura, as demais, já na segunda época, seu peso foi inferior quando comparado a primeira época. A produtividade não apresentou diferença significativa entre todas as quatro cultivares testadas nas duas épocas de semeadura. Ao ser contabilizadas todas as perdas e convertido estas ao custo inicial de sementes utilizadas para semeadura gera uma receita que apresenta perdas que resultam em menor produtividade deixando de produzir uma receita adicional que pode ser utilizada dentro da própria empresa agrícola. 


\section{INTRODUCTION}

The soybean (Glycine Max (L.) Merrill) originated in Asia, and its habit of growth was low, but with the evolutionary process, which occurred by natural crosses, wild species were domesticated and used in cultivation with erect growth habit.

Soybean cultivation is a high-risk activity because it depends exclusively on the climate and technology that will be used in this activity (Mello Filho et al., 1995).

According to calculations by the Center for Advanced Studies in Applied Economics (Cepea), the soybean crop $(2015 / 16)$ may have one of the highest operating costs in recent years. In addition to the strong appreciation of the US dollar against the real, labor increases and rising interest rates on fuel, fuel and electricity increased the expenses of producers at the end of the 2014/15 season (CEPEA, 2016).

The soybean market for the Brazilian farmer is in favorable conditions, with stable prices that do not suffer very large variations compared to other grain crops such as beans and corn for example.

According to the Ministry of Agriculture (MAPA), soybeans occupy $49 \%$ of the area planted in Brazil, it is the agricultural culture that has grown the most in the last three decades. INTACTA RR2 PRO TM technology, for example, combines three benefits never seen together: unprecedented productivity results due to advanced technologies in mapping, selecting and inserting genes into regions of DNA with positive potential in productivity; protection of the main caterpillars that attack the soybean crop; and tolerance to glyphosate provided by Roundup Ready (RR) technology (MONSANTO, 2013).

The use of this technology adds to the production of soybeans, due to the resistance of the plant to the attack of some species of caterpillars. The attack of leptoptera (caterpillars) damages a great part of the soybean crop, occurring loss of defoliation in severe cases reaching $100 \%$.

The American multinational Monsanto launched in 2013 the intact transgenic soybean RR2 PRO, which has Bt technology, in which it generates a resistance of the plant to the attack of the main caterpillars causing damages in this crop.

Always aiming at increasing profit, producers are looking for ways to reduce production costs, spending less on inputs and optimizing productivity for each crop.

The main pests that the technology presents, in addition to the effective control of soybeans, are: soybean caterpillar (Anticarsia gemmatalis), false medlar caterpillar (Chrysodeixis includens and Rachiplusia nu), axillary drill, also known as (Crocidosema aporema) - and apple caterpillar (Heliothis virescens). The INTACTA RR2 PRO TM technology also suppresses the elasmotype caterpillar (Elasmo palpuslignoselis).

According to employees of Cepea, in the region of Rio Verde (GO), the harvest of the first season is already finished, with average productivity 42 and 44 bags/ha on harvest of 2015/16, slightly below the previous harvest of 45 bags/ha. There were losses of up to $20 \%$ of the 
production due to the drought at the beginning of the cycle, besides the incidence of the false medlar caterpillar (Chrysodeixis includens), mainly from the middle to the end of the crop development (CEPEA, 2015).

The objective of this work was to analyze the technical performance and economic viability of soybean cultivars in two sowing seasons, one with Roundup Ready (RR) technology and another with INTACTA RR2 PRO TM technology.

\section{MATERIALS AND METHODS}

The geographic coordinates and average altitude, respectively, were: latitude of $17^{\circ} 47^{\prime} \mathrm{S}$, longitude of $50^{\circ} 57^{\prime} \mathrm{W}$ and 715 meters of altitude. The experiment was carried out at the Center for Agricultural Research - CPA, located in Rio Verde, Goiás state, and the trial was conducted during the period from October 2015 to March 2016.

Maximum, minimum and rainfall precipitation were collected during the soybean cultivation period, which was october 2015 to march 2016 (Figure 1). During the period of conduction of the tests an amount of $1,787.6 \mathrm{~mm}$ of rainwater was verified in the CPA area.

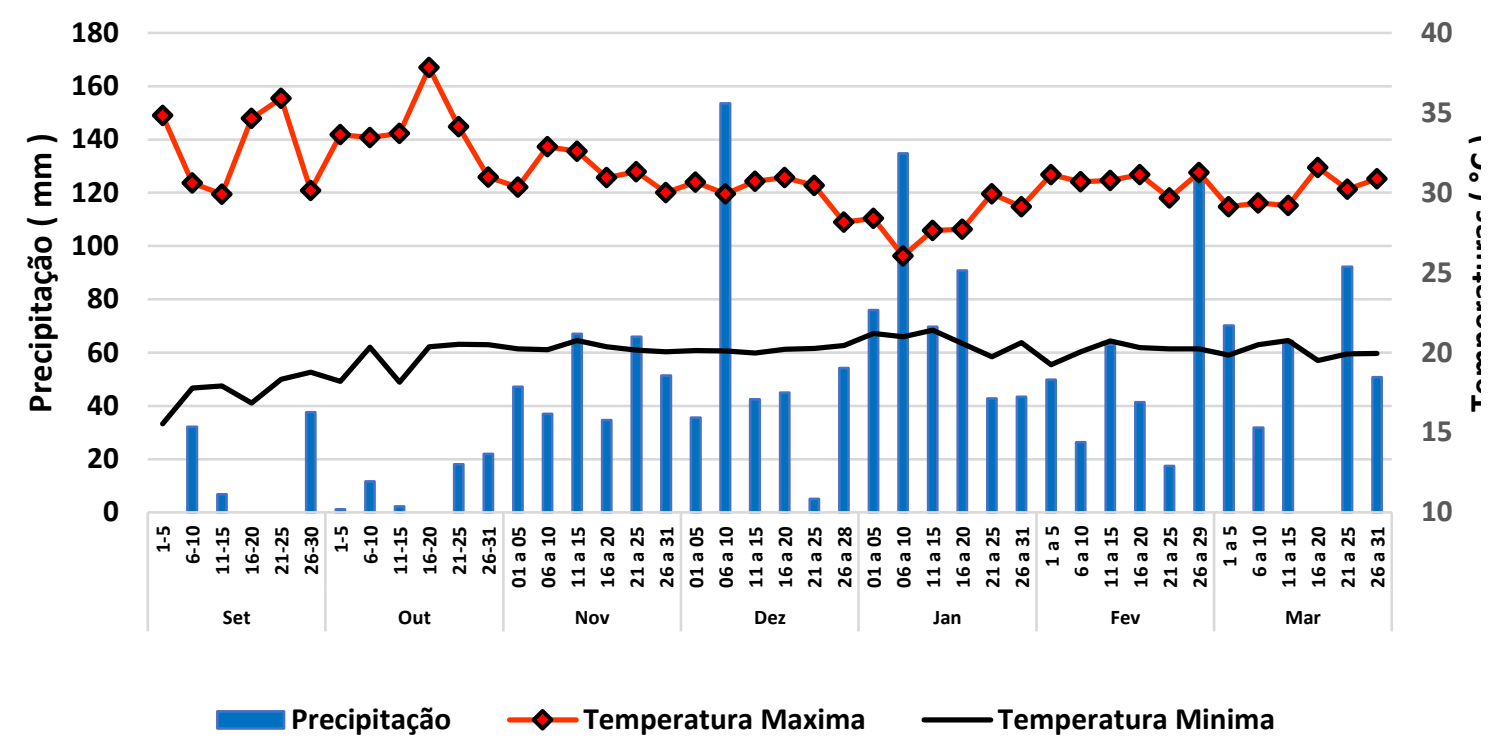

Figure 1. Minimum, maximum and rainfall temperatures in Rio Verde, GO.

The soil of the experimental area is classified as a dystrophic Red Latosol, according to the Brazilian soil classification system (EMBRAPA, 2006) and the cultivation area is under no-tillage system.

The soil was sampled at depth of 0 to 20 $\mathrm{cm}$ for physical-chemical characterization as containing: sand, silt and clay: $41 \%, 12 \%$ and $47 \%$, respectively; MW: 3.06 g. $\mathrm{dm}^{-3}, \mathrm{pH}\left(\mathrm{CaCl}_{2}\right)$ : 4.68; Ca: 1.29 cmolc. $\mathrm{dm}^{-3}$; Mg: 0.69 cmolc. $\mathrm{dm}^{-3} ; \mathrm{Al}^{3+}$ : 0.09 cmolc dm-3; $\mathrm{H}^{+} \mathrm{Al}: 2.95$ cmolc.dm $^{-3}$; P: 8.75 mg.dm ${ }^{-3}$; K: 55 mg.dm ${ }^{-3}$; Cu: $1.96 \mathrm{mg} \cdot \mathrm{dm}^{-3}$; Fe: $58.65 \mathrm{mg} \cdot \mathrm{dm}^{-3}$; Mn: $31.99 \mathrm{mg} \cdot \mathrm{dm}^{-3}$; Zn: 3.08 
mg.dm ${ }^{-3} ; \mathrm{SB}: 2.12 \mathrm{cmol}_{\mathrm{dm}}{ }^{-3} ; \mathrm{T}: 5.07 \mathrm{cmol}^{\mathrm{dm}} \mathrm{dm}^{-3}$ and V: $41.08 \%$.

The experimental design was randomized blocks, in a $4 \times 2$ factorial scheme, four soybean cultivars were used, the first factor was two varieties with the intact technology that is resistant to some pests and resistant to the use of the herbicide glyphosate for plant control (M 7110 IPRO and M 7739 IPRO) and two varieties with RR technology resistant to the use of glyphosate herbicide in the control of involuntary plants (TMG7262 RR and SYN 1163 RR), and the second factor 2 planting times, namely: first at the end of October (on 10/31/2015) and the second, ten days after (on 11/11/2015), with four replications. The plots were composed of eight rows of 8 meters in length with a spacing of $0.50 \mathrm{~m}$ between rows. The evaluations were carried out in the two central rows, leaving $1.5 \mathrm{~m}$ of border at the extremities and $3.0 \mathrm{~m}$ at the lateral ends leaving a useful area of 5.0 $\mathrm{m}^{2}$.

The M 7110 IPRO (precocious with undetermined growth), M 7739 IPRO (precocious with semi-determined growth), TMG 7262 RR (early with semi-determined growth) and SYN 1163 RR (early with undetermined growth) were sown with seeder-fertilizer (SPD), using 300,000 viable seeds per hectare for the M 7110 IPRO and M7739 IPRO varieties and 500,000 viable seeds per hectare for the TMG 7262 RR and SYN 1163 $\mathrm{RR}$ varieties. The basic fertilization in the soybean crop followed the procedures of the commercial crop, in which were applied in the sowing furrow $250 \mathrm{~kg} / \mathrm{ha}$ of the formulated 00-20-20.
For the treatment of seeds, insecticides with active ingredients (IMIDACLOPRIDO 150 $\mathrm{g} / \mathrm{L}+$ TIODICARBE $450 \mathrm{~g} / \mathrm{L}$ ) were used in the package leaflet $300 \mathrm{ml} 100 \mathrm{~kg}$ and fungicides (CARBENDAZIN $150 \mathrm{~g} / \mathrm{L}+$ TIRAN $350 \mathrm{~g} / \mathrm{L}$ ) at $150 \mathrm{ml} .100 \mathrm{~kg}$ of $\mathrm{seed}^{-1}$. The inoculation was done with the bacterium Bradyrbizobium elkaniibr $5 \times 109 \mathrm{CFU} / \mathrm{ml}$, in the dose $300 \mathrm{ml} .100 \mathrm{~kg}$ of seed 1.

Cultural treatments and phytosanitary management of the experimental plots followed the same procedures adopted in the soybean commercial crop, including pest and disease monitoring, insecticide and fungicide applications when necessary, and chemical weed control, in accordance with the technical recommendations of the culture and technology requirements.

For the cultivars M7110 IPRO and M7739 IPRO, 3.5 L.ha ${ }^{-1}$ of Roundup transorb were used in the desiccation before planting and 2 L.ha $^{-1}$ of Roundup transorb associated with Cletodim + mineral oil (240 g.L $\mathrm{L}^{-1}+428$ g.L $\left.\mathrm{L}^{-1}\right)$, at the doses of $0.8+1$ L.ha ${ }^{-1}$ applied in emergent powders. Two sprays were applied with the fungicide Trifloxystrobin + Prothioconazole (150 g. $\mathrm{L}^{-1}+$ 175 g.L $\left.\mathrm{L}^{-1}\right)$ at the dose of $400 \mathrm{ml} . \mathrm{ha}^{-1}$ applied with 15 days of interval from the first to the second, both associated with mineral oil at dose $0,25 \%$ of the volume of the syrup. Two doses of $200 \mathrm{ml}^{-\mathrm{ha}^{-1}}$ of Trifloxystrobin + Ciproconazole $\left(375\right.$ g.L $\mathrm{L}^{-1}+160$ g. $\mathrm{L}^{-1}$ ) were associated with the insecticides Spiromesifene and Imidacloprid + Beta-Cyfluthrin $\left(240\right.$ g. $\mathrm{L}^{-1}+100$ g. $\mathrm{L}^{-1}+12.5$ g. $\left.\mathrm{L}^{-1}\right)$, at $500 \mathrm{ml} \cdot \mathrm{ha}^{-1}+$ 
1 L.ha ${ }^{-1}$, both mixed in tank with mineral oil at $0.25 \%$ volume of the syrup volume.

In soybean cultivars SYN1163 RR and TMG7262 RR, the products used throughout their cycle did not differ from the products used in the intact cultivars mentioned above, but there was an increase in the use of insecticides for caterpillar control, with two applications of Flubendiamide (480 g. $\mathrm{L}^{-1}$ i.a.), at the dose of $100 \mathrm{ml} \cdot \mathrm{ha}^{-1}$, when the soybean was at the reproductive stages R1 and R2. At ten days after the second application, the insecticide Indoxicarbe (150 g. $\left.\mathrm{L}^{-1}\right)$ was sprayed in the plots, at a dose of $400 \mathrm{ml}_{\mathrm{ha}}{ }^{-1}$.

The desiccation and post-emergence management of the soybean were carried out using a Jacto sprayer (AM 14) with tank capacity of 800 liters, coupled to the Ford / New Holand TL75E $4 \times 2$ tractor hydraulics.

The M7110 IPRO and M7739 IPRO varieties closed the harvest cycle in the first season with 100 and 120 days after sowing and, in the second season, with 109 and 117 days, respectively. The other materials TMG7262 RR and SYN1163 RR closed the first season cycle with 100 days, in second season, with 109 days after planting.

Harvesting of the experimental plots was carried out manually in the 2 central lines with 4 meters length in each plot $\left(8 \mathrm{~m}^{2}\right)$ in which the average mass of the grains per plot was estimated and the crop productivity, the weight of a thousand grains, the number of pods per plant, the number of grains in 20 plants randomly chosen in the useful area and the final stand.
The initial stand evaluations with the crop in the vegetative stage in V3 and final stand in preharvest, being evaluated 10 meters long in the two central lines in the four replicates of each soybean cultivar.

Correction was made to estimate productivity because moisture content was above $17 \%$. Thus, all values were adjusted and converted to $(14 \%)$ moisture for estimates in bags per hectare, the mass of one thousand grains was determined manually by counting the seeds and weighing them in digital scale in grams.

The agronomic characteristics were analyzed statistically by the Tukey test at 5\% probability, and in order to determine the costs of each treatment (Ti), we used the concept of operational cost, described by Matsunaga et al. (1976), calculated as follows:

a) effective operational cost of treatment (COEi), which includes all explicit expenses or those in which monetary expenditures occur, such as: expenses with pesticides, seeds, fertilizers and others for the treatment, in addition to expenses with the labor force; the soybean harvest will be calculated according to the local market, the cost being incorporated into the $\mathrm{COE}$;

b) the total operational cost (COTi) of each treatment, which includes the COE plus the depreciation value and the remuneration of the rural entrepreneur; and

c) the total cost of the treatments (CTi), which is the result of the sum between the TOC and the opportunity costs of the capital (tractors, 
sprayers and planters) and land used in the production process.

The indicators of profitability analysis for the treatments used in the study were (MARTIN et al., 1998):

(a) Total gross revenue (RBTi) of the treatment: revenue obtained from the sale of the product, the result of the product between the volume collected in treatment i (Yi), in bags.ha ${ }^{-1}$, and the selling price of one bag $(\mathrm{P})$ in $\mathrm{R} \$$, given by the following expression: $\mathrm{RBTi}=(\mathrm{Yi} * \mathrm{P})$;

b) Operational Net Revenue (RLOi) of the treatment, also called operating profit, is the result of the difference between the RBTi and the total operational cost (COTi) in each treatment, obtained by the following expression: RLOi = RBTi-COTi;

c) Gross Margin (MBi) of the treatment, margin (index) that evaluates the return obtained after the revenue cover the TOC, in percentage, in relation to the TOC itself, given by the following expression: $\mathrm{MBi}=((\mathrm{RBTi}-\mathrm{COTi}) / \mathrm{COTi}) * 100$

d) Index of Profitability (ILi) of the treatment, obtained by the ratio between RLO and RBT, expressed as a percentage, obtained by the following expression: $\mathrm{ILi}=((\mathrm{RLOi} / \mathrm{RBTi}) * 100)$;

e) Leveling Point (PNi): determined by the relationship between the TOC and the unit cost of the product $(\mathrm{P})$, according to the expression: $\mathrm{PNi}$ $=\mathrm{COTi} / \mathrm{P}$, evaluates how many bags are needed to cover COTi);

f) Equilibrium Price (PEI): is the minimum price to be obtained to cover the total operating cost taking into account the average productivity of the activity in each treatment (Yi), per unit area, obtained by the expression: $\mathrm{PEi}=\mathrm{COTi} / \mathrm{Yi}$.

The adjusted total gross revenue (RBTA) was also calculated, which should have been received by the producer if there were no plant losses at the final stand at the time of harvest and is the result of the sum between the RBT and the amount not received due (RBTperdi), obtained by the expression: $\mathrm{RBTAi}=\mathrm{RBTi}+\mathrm{RBTperdi}$. The gross income lost was obtained by the equation: RBTperdi $=($ Qgrans $*$ Pgrão $*$ P $) / 60,000$, where:

a) Qgrãos: quantity of lost grains, given by the relation between the number of plants lost in the final stand and the average amount of grains per plant, in quantity of grain hä ${ }^{-1}$;

b) Pgrão: is the average weight of a grain of the plot, in grams;

c) $\mathrm{P}$ : is the value received by the producer for each bag sold on the market at the time of harvest, in $\mathrm{R} \$$ / bag.

In the same way, the total net rent (RLTi) of each treatment is calculated by the difference between the RBTi and the total cost (CTi) and represents the net profit with the activity, what is left after having paid all the costs, and is obtained by the expression RLTi $=$ RBTi-CTi; the adjusted total net revenue (Adjusted RLT) is the result of the difference between the RBTajustadai of each treatment and the CTi.

The prices of production inputs and sales of oilseed were obtained in the market of Rio Verde (GO), in the period in focus of the respective productions and commercializations. At 
the time of harvest, the soybean bag in the region was priced at $\mathrm{R} \$ 65.00$. The economically feasible treatment is one that has a positive operating RESULTS AND DISCUSSION profit. The best is the one that presents higher LO, IL and MB and lower PN and PE.

The results of variance analysis (Table 1) for the analyzed characteristics presented significance for the treatments $(\mathrm{p}<0,05)$.

Table 1. Statistical variance analysis of soy - Rio Verde (GO).

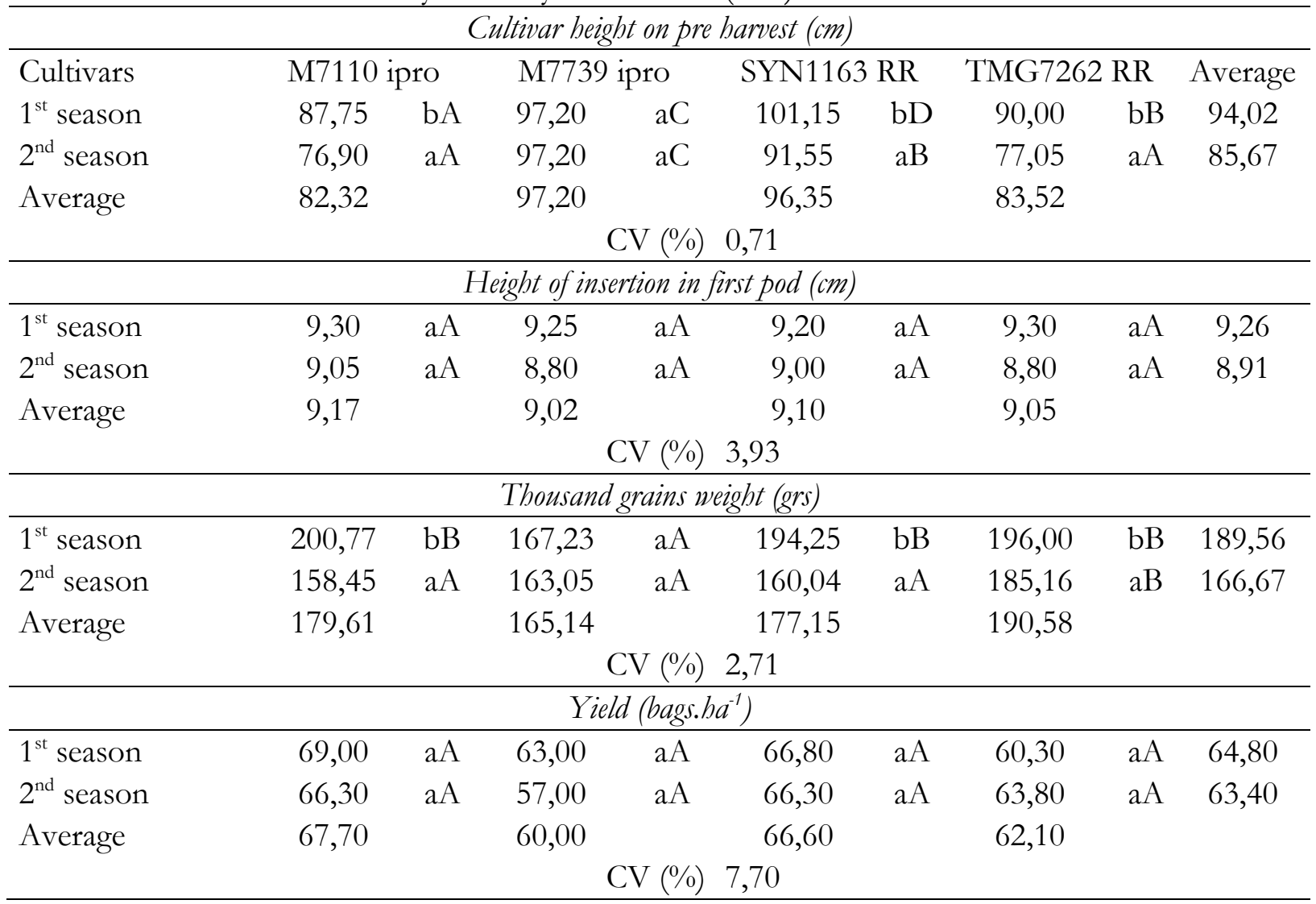

Averages follow by same lowercase letter in column and upper case in row do not differ by Tukey Test at $5 \%$.

The height evaluations of preharvest plants of the varieties M7110 IPRO, SYN1163 RR and TMG 7262 RR presented differences between them; already in the variety M7739 IPRO, there were no differences in height independent of the planting season. Observing the first season, all cultivars showed differences in plant height, since in the period from December to January the region was approximately 20 days of cloudiness and precipitation, directly influencing its vegetative development. In the second period, only the material M7739 IPRO did not differ in the height of plants, the other materials presented reduction of size.

In the evaluation of first pod insertion, there were no significant differences in the two planting seasons in the M7110 IPRO, M7739 IPRO, SYN1163 RR and TMG 7262 RR varieties. In the weight of a thousand grains, in the varieties M7110 IPRO, SYN1163 RR and TMG 
7262 RR there was statistical difference between them; already in the variety M7739 IPRO did not occur statistical difference, since the time of planting and the weight of a thousand grains did not change. When analyzing the first season among the varieties, presented a difference only of material M7739 IPRO, being inferior of the others. Already in the second season, only the variety TMG 7262 RR differed from the others, with a weight higher than a thousand grains.

In the analysis of productivity, when analyzing the varieties M7110 IPRO, M7739
IPRO, SYN1163 RR and TMG7262 RR, the statistical analysis was not significant between the varieties in the two planting seasons, thus, these varieties showed good adaptation in the two sowing seasons.

The results showed that there were considerable losses in the establishment of the crop and also in the final stand and there were variations both in terms of cultivars and sowing time (Table 2 and Figure 2).

Table 2. Average percentage values of plants established in the initial and final stands in the soybean crop (plants.ha ${ }^{-1}$ )

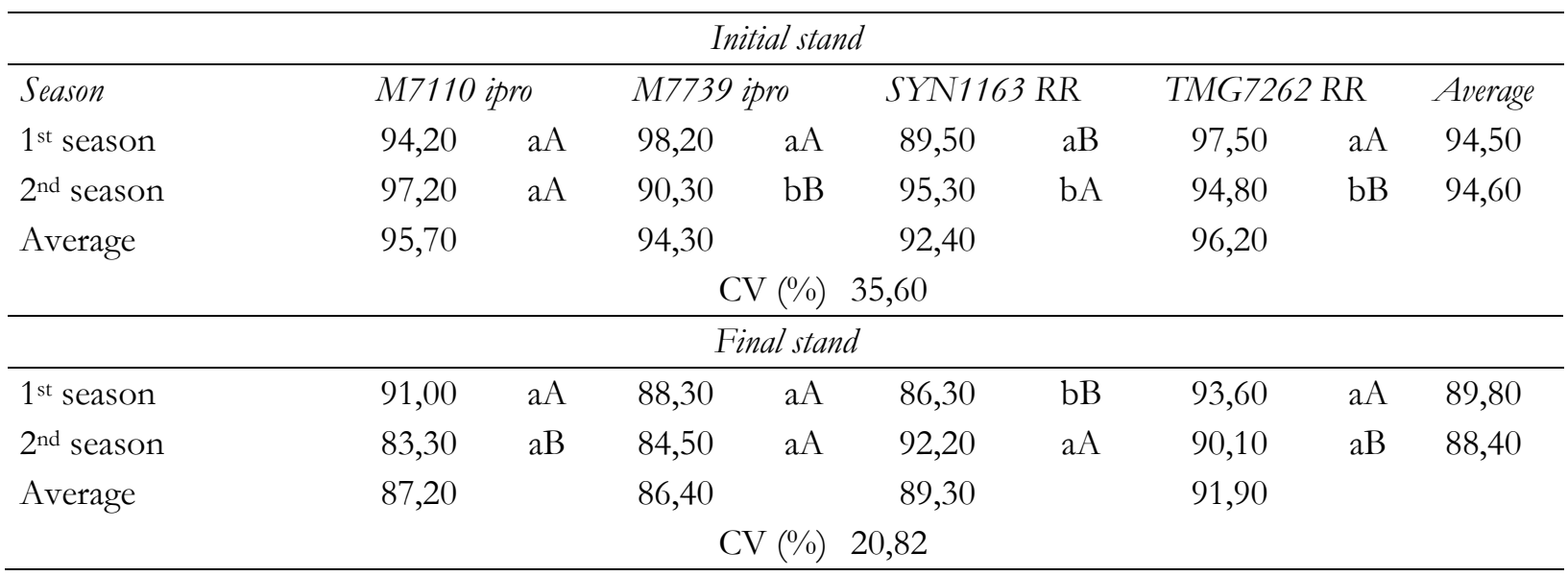

Averages follow by same lowercase letter in column and upper case in row do not differ by Tukey Test at 5\%.

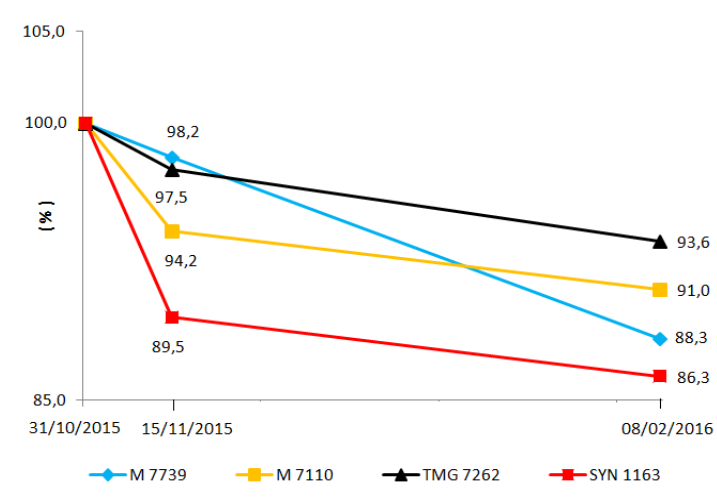

(A)

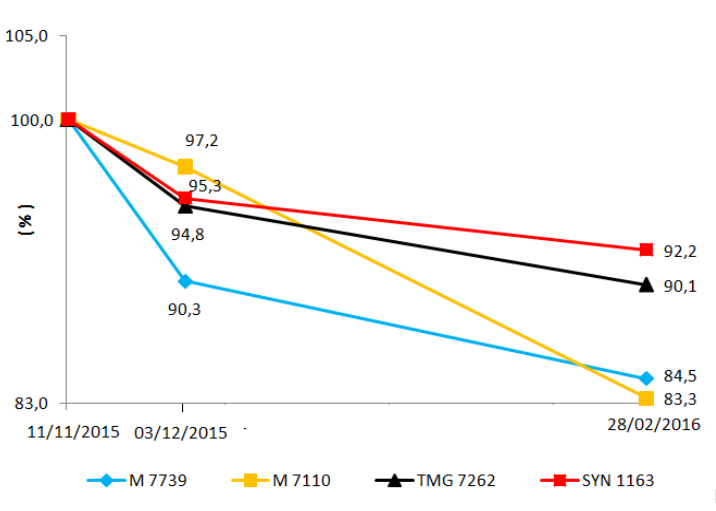

(B)

Figure 2. Plants evolution established in stands on first season (A) and second season (B). 
The results showed different behaviors of the cultivars in relation to the sowing time, as for the percentage of losses. In the second season, with the climate already established, the attack of pests such as birds and insects were greater than the sowing period of the first season, with this, the stand was compromised, affecting the initial and final booth of the second season. However, there are losses in both seasons, with higher losses in the second season, because they reduced the revenue, due to the lower amount of grain harvested, due to the lower harvest, which impacted the final revenue (Table 4). Associating, in this way losses of plants in the stands and the weight of obtained revenue that were left to gain in the conduction of the plantations (Table 5).

Table 3. Mean values between soybean hybrids sown in two seasons

\begin{tabular}{|c|c|c|c|c|c|}
\hline $1^{\text {st }}$ season & Unidades & M7739IPRO & M7110IPRO & TMG7262RR & SYN1163RR \\
\hline Pods.p. $\mathrm{l}^{-1}$ & $\mathrm{Ud}$ & 29 & 36 & 23 & 31 \\
\hline Grains.p $\mathrm{l}^{-1}$ & $\mathrm{Ud}$ & 68 & 92 & 64 & 64 \\
\hline NPP & Ud.ha ${ }^{-1}$ & 35,100 & 27,000 & 32,000 & 68,500 \\
\hline Qgrãos & Ud.ha' ${ }^{-1}$ & $2,379,780$ & $2,473,200$ & $2,033,600$ & $4,401,125$ \\
\hline Pgrão & Grs.ud ${ }^{-1}$ & 0.1672 & 0.2008 & 0.1960 & 0.1943 \\
\hline Pperdido & Grs.ha ${ }^{-1}$ & 397,899 & 496,619 & 398,586 & 855,139 \\
\hline Pperdido & Bags.ha $^{-1}$ & 6.6 & 8.3 & 6.6 & 14.3 \\
\hline RBTperdida & $\mathrm{R} \$ \cdot \mathrm{ha}^{-1}$ & 431.06 & 538.00 & 431.80 & 926.40 \\
\hline $2^{\text {nd }}$ season & Unidades & M7739IPRO & M7110IPRO & TMG7262RR & SYN1163RR \\
\hline Pods.pl ${ }^{-1}$ & $\mathrm{Ud}$ & 34 & 31 & 28 & 28 \\
\hline Grains.pl ${ }^{-1}$ & $\mathrm{Ud}$ & 81 & 75 & 72 & 74 \\
\hline NPP & Ud.ha ${ }^{-1}$ & 46,500 & 50,100 & 49,500 & 39,000 \\
\hline Qgrãos & Ud.hat ${ }^{-1}$ & $3,766,500$ & $3,757,500$ & $3,564,000$ & $2,886,000$ \\
\hline Pgrão & Grs.ud $^{-1}$ & 0.1631 & 0.1585 & 0.1852 & 0.1600 \\
\hline Pperdido & Grs.ha $^{-1}$ & 614,316 & 595,564 & 660,053 & 461,760 \\
\hline Pperdido & Bags.ha ${ }^{-1}$ & 10.2 & 9.9 & 11.0 & 7.7 \\
\hline RBTperdida & $\mathrm{R} \$ . h \mathrm{~h}^{-1}$ & 665.51 & 645.19 & 715.06 & 500.24 \\
\hline
\end{tabular}

The values not received were higher in the second season, except for the material SYN 1163 RR that presented high loss in the first season. The materials presented different losses when analyzing each cultivar in both seasons, in the materials TMG 7262 RR and SYN 1163 RR it was observed that the plant height in these populations showed similarity between them with fine stem, leaving them vulnerable to losses of plants by winds, beddings.

Soil pest attack, in the initial phase, caused a lower booth uniformity in all cultivars studied in this trial. 
Table 4. Costs for soybean production at both sowing times $\left(\mathrm{R} \$ \mathrm{ha}^{-1}\right)$

\begin{tabular}{lrrrr}
\hline & SYN 1163 RR & TMG 7262 RR & M 7110 IPRO & M 7739 IPRO \\
\hline COE & $2.411,55$ & $2.392,63$ & $2.157,13$ & $2.139,10$ \\
Seeds & 462,00 & 457,70 & 413,00 & 420,00 \\
Planting fertilizing & 347,50 & 347,50 & 347,50 & 347,50 \\
Seeds treatment & 64,40 & 64,40 & 64,40 & 64,40 \\
Inoculant & 0,60 & 0,60 & 0,60 & 0,60 \\
Insecticide & 540,50 & 540,50 & 331,50 & 331,50 \\
Fungicide & 203,20 & 203,20 & 203,20 & 203,20 \\
Herbicide & 195,40 & 195,40 & 195,40 & 195,40 \\
Mineral oil & 26,50 & 26,50 & 26,50 & 26,50 \\
Fuel & 30,00 & 30,00 & 30,00 & 30,00 \\
Harvest & 216,45 & 201,83 & 220,03 & 195,00 \\
Labor & 325,00 & 325,00 & 325,00 & 325,00 \\
COT & $2.992,28$ & $2.971,70$ & $2.715,60$ & $2.695,99$ \\
Depreciation & 112,00 & 112,00 & 112,00 & 112,00 \\
Social charges & 107,25 & 107,25 & 107,25 & 107,25 \\
Social security & 85,47 & 85,47 & 85,47 & 85,47 \\
Financial charges & 211,01 & 209,35 & 188,75 & 187,17 \\
Technical assistance & 65,00 & 65,00 & 65,00 & 65,00 \\
Total Cost & $3.554,28$ & $3.533,70$ & $3.277,60$ & $3.257,99$ \\
Land remuneration & 480,00 & 480,00 & 480,00 & 480,00 \\
Machines remuneration $^{2}$ & 82,00 & 82,00 & 82,00 & 82,00 \\
\hline Socil chargen
\end{tabular}

${ }^{1}$ Social charges: $33 \%$ over MDO; ${ }^{2}$ Social security: $2,2 \%$ over RBT; ${ }^{3}$ Financial charges: $8,75 \%$ over COE;

${ }^{4}$ Technical assistance: 1 soy bag.ha- ${ }^{-1}$.

Table 5. Average values of economic performance of the cultivars in focus in the soybean crop

\begin{tabular}{|c|c|c|c|c|}
\hline Itens & M 7110 IPRO & $M 7739$ IPRO & TMG $7262 \mathrm{RR}$ & SYN $1163 \mathrm{RR}$ \\
\hline $\mathrm{COE}$ & $2.157,13$ & $2.139,10$ & $2.392,63$ & $2.411,55$ \\
\hline COT & $2.715,60$ & $2.695,99$ & $2.971,70$ & $2.992,28$ \\
\hline CT & $3.277,60$ & $3.257,99$ & $3.533,70$ & $3.554,28$ \\
\hline \multicolumn{5}{|c|}{$1^{\text {st }}$ season } \\
\hline Revenue (bags.ha ${ }^{-1}$ ) & 69.00 & 63.00 & 60.30 & 66.80 \\
\hline $\mathrm{RBT}\left(\mathrm{R} \$ \cdot h \mathrm{~h}^{-1}\right)$ & $4,485.00$ & $4,095.00$ & $3,919.50$ & $4,342.00$ \\
\hline RBTajusted (R\$.ha $\left.{ }^{-1}\right)$ & $5,023.00$ & $4,526.06$ & $4,351.30$ & $5,268.40$ \\
\hline RLOperational ( $\left.\mathrm{R} \$ \mathrm{ha}^{-1}\right)$ & $1,769.40$ & $1,399.01$ & 947.80 & $1,349.72$ \\
\hline $\operatorname{RLT}\left(\mathrm{R} \$ \mathrm{ha}^{-1}\right)$ & $1,207.40$ & 837.01 & 385.80 & $1,349.72$ \\
\hline RLT ajusted $\left(\mathrm{R} \$ . h \mathrm{~h}^{-1}\right)$ & $1,745.40$ & $1,268.70$ & 817.60 & $1,714.12$ \\
\hline $\operatorname{MBT}(\%)$ & 65.16 & 51.89 & 31.89 & 45.11 \\
\hline IL $(\%)$ & 39.45 & 34.16 & 24.18 & 31.09 \\
\hline PN (bags.ha ${ }^{-1}$ ) & 41.78 & 41.48 & 45.72 & 46.04 \\
\hline $\operatorname{Peq}\left(\mathrm{R} \$ . \mathrm{bags}^{-1}\right)$ & 39.36 & 42.79 & 49.28 & 45.13 \\
\hline
\end{tabular}




\begin{tabular}{|c|c|c|c|c|}
\hline \multicolumn{5}{|c|}{$2^{\text {nd }}$ season } \\
\hline Revenue (bags.ha ${ }^{-1}$ ) & 66.30 & 57.00 & 63.80 & 66.30 \\
\hline $\mathrm{RBT}\left(\mathrm{R} \$ \cdot \mathrm{ha}^{-1}\right)$ & $4,309.50$ & $3,705.00$ & $4,147.00$ & $4,309.50$ \\
\hline RBTajusted $\left(\mathrm{R} \$ \cdot \mathrm{ha}^{-1}\right)$ & $4,954.69$ & $4,370.51$ & $4,862.06$ & $4,809.74$ \\
\hline RLOperational $\left(\mathrm{R} \$ \mathrm{ha}^{-1}\right)$ & $1,593.90$ & $1,009.01$ & $1,175.30$ & $1,317.22$ \\
\hline $\operatorname{RLT}\left(\mathrm{R} \$ \mathrm{ha}^{-1}\right)$ & $1,031.90$ & 447.01 & 613.30 & 755.22 \\
\hline RLT ajusted $\left(\mathrm{R} \$ . \mathrm{ha}^{-1}\right)$ & $1,677.09$ & $1,112.52$ & $1,328.36$ & $1,255.46$ \\
\hline $\operatorname{MBT}(\%)$ & 58.69 & 37.43 & 39.55 & 44.02 \\
\hline IL (\%) & 36.99 & 27.23 & 28.34 & 30.57 \\
\hline PN (bags.hat $\left.{ }^{-1}\right)$ & 41.78 & 41.48 & 45.72 & 46.04 \\
\hline Peq $\left(\mathrm{R} \$\right.$ bags $\left.^{-1}\right)$ & 39.36 & 42.79 & 49.28 & 45.13 \\
\hline
\end{tabular}

However, the materials presented lower losses in the first season, making it clear that the earlier the producer sows the crop, the better the final stand, which will lead to higher yields. Thus, producers could have incorporated these values into revenue.

\section{CONCLUSIONS}

The planting season, ranging from $10 / 31 / 2015$ to $11 / 11 / 2015$, does not interfere in the productive potential of the evaluated cultivars (M7739 IPRO, M7110 IPRO, SYN1163 RRe TMG 7262 RR).

\section{REFERENCES}

CENTRO DE ESTUDOS AVANCADOS EM ECONOMIA APLICADA (CEPEA), Custo de produção agrícola. Disponível em http://cepea.esalq.usp.br/soja/custos/2015/01F ev_Abr.pdf

Monsanto mostra vantagens da Tecnologia RR2 IPRO na Agrobrasília 2013. Disponível em : http://www.agrobrasilia.com.br/ultimasnoticias/322-monsanto-mostra-vantagens-datecnologia-intacta-rr2-pro-na-agrobrasilia2013.html

MELO FILHO, G.A. DE; KRUKER, J.M. 1990. Custo de produção de trigo na região de Dourados, MS - safra 1990. Dourados: EMBRAPA-UEPAE Dourados. 11p. (EMBRAPA-UEPAE Dourados. Comunicado Técnico, 38). 